\title{
ANALISIS RASIO KEUANGAN SEBAGAI ALAT UKUR KINERJA PERUSAHAAN PADA PT. ASTALIA MILLENIA EDUCATINDO CABANG MADIUN
}

\author{
Satriyo Budiwibowo \\ IKIP PGRI Madiun
}

\begin{abstract}
This study aims to determine the company's financial performance, both in terms of liquidity, solvency, profitability and activity of PT .Millennia Astalia Educatindo Madiun from 2010 until 2012. The processed data is the data that comprises the financial statements of the balance sheet and income statement. Methods of data processing by using ratio analysis consisting of the ratio liquidity, profitability, solvency and activities. The method used is descriptive method, the research seeks to collect and present data from the company to be analyzed so as to provide a fairly clear picture of the object under study. Because of financial ratios is one tool in evaluating the company's financial condition and performance, it is expected that through the analysis of financial statements may consideration in making decisions, especially regarding the financial condition in the future. Besides, the analysis of financial statements to describe the company's actual financial performance. The results showed that the ratio of liquidity include the current ratio and quick ratio increased, although still below the industry average. For profitability ratios include gross profit margin and operating profit margin increased in 2012 despite the decline was due to the increased cost of goods sold. Solvency ratios while covering a total debt to equity ratio and total debt to capital assets shows a marked improvement by decreasing solvency ratio from year to year. Nonetheless Solvency ratio still can't to be categorized either as it is still above the industry average. The ratio of activity which includes receivable turnover and total asset turnover has fluctuated, rising in 2011 but dropped in 2012. Nonetheless Activity ratios are well below the industry average, which means the company has not been effective in utilizing existing resources.
\end{abstract}

Keywords : Financial Analysis, Financial Ratios, Company Performance .

\begin{abstract}
ABSTRAK
Penelitian ini bertujuan untuk mengetahui kinerja keuangan perusahaan, baik dari sisi likuiditas, solvabilitas, profitabilitas dan aktifitas PT. Astalia Millenia Educatindo Cabang Madiun mulai tahun 2010 sampai dengan tahun 2012. Data yang diolah adalah data laporan keuangan yang terdiri dari neraca dan laporan laba rugi. Metode pengolahan data dengan mengunakan analisis rasio yang terdiri dari rasio Likuiditas, Profitabilitas, Solvabilitas dan Aktivitas. Metode penelitian yang digunakan adalah metode deskriptif, yaitu penelitian yang berusaha mengumpulkan dan
\end{abstract}


menyajikan data dari perusahaan untuk dianalisis sehingga memberikan gambaran yang cukup jelas atas objek yang diteliti. Karena rasio keuangan merupakan salah satu alat dalam mengevaluasi kondisi keuangan dan kinerja perusahaan, maka diharapkan melalui analisis laporan keuangan dapat dijadikan pertimbangan dalam mengambil keputusan terutama mengenai kondisi keuangan di masa yang akan datang. Disamping itu hasil analisis laporan keuangan dapat menggambarkan kinerja keuangan perusahaan yang sebenarnya.

Hasil penelitian menunjukkan bahwa rasio Likuiditas yang meliputi current ratio dan quick ratio mengalami peningkatan meskipun masih dibawah rata-rata industri. Untuk rasio Profitabilitas yang meliputi gross profit margin dan operating profit margin mengalami peningkatan meskipun di tahun 2012 sempat menurun dikarenakan harga pokok penjualan meningkat. Sedangkan rasio Solvabilitas yang meliputi total debt to equity ratio dan total debt to capital asset menunjukkan peningkatan yang ditandai oleh menurunnya rasio solvabilitas dari tahun ke tahun. Meskipun demikian rasio Solvabilitas masih belum bisa dikategorikan baik karena masih di atas rata-rata industri. Rasio Aktivitas yang meliputi receivable turnover dan total asset turnover mengalami fluktuasi, meningkat ditahun 2011 namun turun ditahun 2012. Meskipun demikian rasio Aktivitas berada jauh di bawah rata-rata industri, yang artinya perusahaan belum efektif dalam memanfaatkan sumber daya yang ada.

Kata kunci: Analisis Keuangan, Rasio Keuangan, Kinerja Perusahaan.

\section{PENDAHULUAN}

Seiring dengan meningkatnya pertumbuhan ekonomi di Indonesia, semakin banyak pula persaingan yang terjadi dalam dunia bisnis. Banyak pesaing-pesaing mulai dari tingkat nasional sampai tingkat multinasional. Persaingan ini membuat para pengusaha memperkuat perusahaannya mulai dari segi pemasaran, promosi, dan keuangan perusahaan. Namun hampir semua perusahaan mengalami masalah yang sama yaitu bagaimana mengalokasikan sumber daya yang dimiliki guna mencapai tujuan perusahaan yaitu memperoleh laba maksimal untuk mempertahankan eksistensi perusahaan.

Banyaknya persaingan juga akan membuat para investor lebih jeli memilih perusahaan untuk ditanami modal. Para kreditur juga akan lebih selektif dalam memilih nasabah yang akan mendapat kucuran dana pinjaman. Salah satu faktor yang akan menjadi acuan dan bahan pertimbangan adalah kinerja keuangan perusahaan. Penilaian kinerja keuangan sangat diperlukan bagi manajemen perusahaan untuk meningkatkan kinerja, investor untuk meramalkan laba, kreditur untuk mengevaluasi kemungkinan dibayarnya pinjaman, dan pemerintah terkait dengan pajak. Penilaian kinerja perusahaan dapat dilakukan secara periodik untuk memastikan bahwa tujuan perusahaan dapat tercapai dan mengetahui sejauh mana efektifitas perusahaan dalam mencapai tujuan.

Kinerja keuangan dapat dilihat dari laporan keuangan perusahaan. Laporan keuangan umumnya disajikan untuk memberi informasi mengenai posisi-posisi keuangan, kinerja dan arus kas perusahaan dalam periode tertentu. Informasi yang 
dihasilkan laporan keuangan diharapkan juga dapat membantu manajemen perusahaan dalam mengambil keputusan. Laporan keuangan harus memberikan data keuangan yang relevan dan sesuai prosedur sehingga laporan keuangan dapat dibandingkan yang mana tingkat akurasi analisis dapat dipertanggungjawabkan.

Menurut Standar Akuntasi Keuangan (2002:4) tujuan laporan keuangan adalah sebagai berikut:

1. Menyediakan informasi yang menyangkut posisi keuangan, kinerja serta perubahan posisi keuangan suatu perusahaan yang bermanfaat bagi sejumlah besar pemakai dalam mengambil keputusan ekonimi.

2. Laporan keuangan disusun untuk memenuhi kebutuhan bersama oleh sebagian besar pemakainya, yang secara umum menggambarkan pengaruh keuangan dari kejadian masa lalu.

3. Laporan keuangan juga menunjukkan apa yang telah dilakukan manajemen atau pertanggungjawaban manajemen atas sumber daya yang dipercayakan kepadanya.

Untuk mengevaluasi laporan keuangan agar dapat menggambarkan kondisi keuangan perusahaan digunakan teknik analisis rasio keuangan. Analisis rasio keuangan merupakan instrumen analisis yang menjelaskan berbagai hubungan dan indikator keuangan yang dapat menunjukkan perubahan dalam kondisi keuangan dan membantu menggambarkan pola perubahan yang digunakan untuk menunjukkan peluang maupun resiko perusahaan dimasa yang akan datang.

Berdasarkan latar belakang tentang perlunya kinerja keuangan PT. Astalia Milenia Educatindo Cabang Madiun, maka ditindak lanjuti dengan melakukan penelitian yang rumusan masalahnya dapat dirinci sebagai berikut:

1. Bagaimana kinerja keuangan PT. Astalia Millenia Educatindo Cabang Madiun dilihat dari tingkat likuiditas?

2. Bagaimana kinerja keuangan PT. Astalia Millenia Educatindo Cabang Madiun dilihat dari tingkat solvabilitas?

3. Bagaimana kinerja keuangan PT. Astalia Millenia Educatindo Cabang Madiun dilihat dari tingkat profitabilitas?

4. Bagaimana kinerja keuangan PT. Astalia Millenia Educatindo Cabang Madiun dilihat dari tingkat aktivitas?

\section{KAJIAN PUSTAKA}

1. Kinerja Keuangan

Informasi akuntansi sangat bermanfaat untuk menilai pertanggungjawaban kinerja manager. Karena penilaian kinerja pada dasarnya merupakan penilaian perilaku manusia dalam melaksanakan peran yang dimainkannya dalam mencapai tujuan organisasi atau perusahaan. Kemungkinan yang lain adalah digunakannya informasi akuntansi bersamaan dengan informasi non akuntansi untuk menilai kinerja manager atau pimpinan perusahaan.

Kinerja keuangan perusahaan merupakan hasil dari banyak keputusan individual yang dibuat secara terus menerus oleh manajemen. Oleh karena itu untuk menilai kinerja keuangan suatu perusahaan, perlu dilibatkan analisa dampak keuangan kumulatif dan ekonomi dari keputusan dan mempertimbangkannya dengan menggunakan ukuran komparatif. 
Pada saat membahas metode penilaian kinerja keuangan perusahaan, pembahasan harus didasarkan pada data keuangan yang dipublikasikan yang dibuat sesuai dengan prinsip akuntansi keuangan yang berlaku secara umum. Pengertian kinerja menurut Kamus Besar Bahasa Indonesia (2005:770) adalah merupakan kata banda (n) yang artinya: 1. Sesuatu yang dicapai, 2. Prestasi yang diperlihatkan, 3. Kemampuan kerja (peralatan).

Kinerja juga didefinisikan sebagai keberhasilan personel dalam mewujudkan sasaran strategi pada empat perspektif keuangan, yaitu customer, proses, pembelajaran dan pertumbuhan. Menurut Mulyadi (2007:415) yang menyebutkan bahwa "Kinerja keuangan adalah penentuan secara periodik efektivitas operasional suatu organisasi dan karyawannya berdasarkan sasaran, standar dan kriteria yang telah ditetapkan sebelumnya".

Secara umum dapat dikatakan bahwa kinerja keuangan adalah prestasi yang dapat dicapai oleh perusahaan dibidang keuangan dalam suatu periode tertentu yang mencerminkan tingkat kesehatan perusahaan. Disisi lain kinerja keuangan menggambarkan kekuatan struktur keuangan suatu perusahaan dan sejauh mana asset yang tersedia, perusahaan sanggup meraih keuntungan. Hal ini berkaitan erat dengan kemampuan manajemen dalam mengelola sumber daya yang dimiliki perusahaan secara efektif dan efisien.

\section{Laporan Keuangan}

Laporan keuangan merupakan dasar atas upaya analisis pada suatu perusahaan, maka terlebih dahulu harus diketahui sifat, cakupan, dan keterbatasannya sebelum menggunakan laporan keuangan sebagai alat analisis. Di dalam PSAK Penyajian Laporan Keuangan (2009:01.5) dinyatakan bahwa "Laporan keuangan adalah suatu penyajian terstruktur dari posisi keuangan dan kinerja keuangan suatu entitas".

Sedangkan menurut Munawir (2010:2) "Laporan keuangan pada dasarnya adalah hasil dari proses akuntansi yang dapat digunakan sebagai alat untuk berkomunikasi antara data keuangan atau aktivitas suatu perusahaan dengan pihakpihak yang berkepentingan dengan data atau aktivitas perusahaan tersebut".

Dalam bukunya Dasar-dasar Pembelanjaan Perusahaan, Bambang Riyanto (2008:327) menyatakan bahwa

"Laporan keuangan memberikan ikhtisar mengenai keadaan finansiil suatu perusahaan, dimana neraca (balance sheet) mencerminkan nilai aktiva, utang dan modal sendiri pada suatu saat tertentu, dan laporan rugi \& laba (income statement) mencerminkan hasil-hasil yang dicapai selama suatu periode tertenti biasanya meliputi periode satu tahun".

\section{Laporan Laba-Rugi (Income Statement)}

Menurut Kasmir (2006:243), "Dalam Laporan ini tergambar jumlah pendapatan dan sumber-sumber pendapatan serta jumlah biaya dan jenis-jenis biaya yang dikeluarkan."

Pengertian Laporan Laba Rugi menurut Munawir (2010:26) adalah "suatu laporan yang sistematis tentang penghasilan, biaya, rugi-laba yang diperoleh oleh suatu perusahaan selama periode tertentu". 
Bentuk penyajian laporan laba-rugi yang biasa digunakan menurut Kasmir (2006:245) dan juga Munawir (2010:26) ada dua bentuk, yaitu:

a) Bentuk tunggal (Singgle step); yaitu dengan menggabungkan semua penghasilan dalam satu kelompok dan semua biaya dalam satu kelompok sehingga laba atau rugi bersih dihitung dengan satu langkah yakni mengurangkan total pendapatan dengan total biaya.

b) Bentuk bertahap (Multiple Step); yang mengelompokkan laba-rugi secara lebih teliti sesuai dengan prinsip yang digunakan secara umum.

\section{Analisis Rasio Keuangan}

Untuk dapat memperoleh gambaran tentang perkembangan finansial suatu perusahaan, perlu mengadakan analisa atau interprestasi terhadap dana finansial dari perusahaan bersangkutan, dimana data finansial itu tercermin didalam laporan keuangan. Ukuran yang sering digunakan dalam analisa laporan keuangan adalah rasio keuangan.

Menurut Dermawan dan Djahotman (2013:36) "Analisis Rasio (Ratio Analisys) merupakan salah satu analisis paling popular dan banyak digunakan karena sangat sederhana yang menggunakan operasi aritmatika, namun interpretasinya sanyat kompleks".

Sedangkan menurut Munawir (2010:64) menyatakan bahwa

"Rasio menggambarkan suatu hubungan atau perimbangan antara suatu jumlah yang lain, dan dengan menggunakan alat analisa berupa rasio ini akan dapat menjelaskan atau memberi gambaran kepada penganalisa tentang baik atau buruknya keadaan atau posisi keuangan suatu perusahaan terutama apabila angka rasio tersebut dibandingkan dengan angka rasio pembanding yang digunakan sebagai standart".

John J. Wild dan K.R. Subramanyam (2011:40) juga mengatakan bahwa "analisis rasio : salah satu alat analisis keuangan yang paling popular dan banyak digunakan".

Dari definisi tersebut diatas, maka dapat disimpulkan analisis rasio keuangan adalah teknik atau alat untuk mengukur prestasi perusahaan dalam hal menentukan tingkat likuiditas, solvabilitas, keefektifan operasi serta derajat keuntungan perusahaan dengan menghubungkan antar pos-pos dalam neraca atau laporan rugilaba atau kombinasi dari keduanya.

\section{METODE PENELITIAN}

Adapun metode penelitian yang digunakan dalam penelitian ini adalah metode deskriptif. Menurut Sugiyono (2012 : 29) "metode deskriptif adalah metode yang digunakan untuk menggambarkan atau menganalisis suatu hasil penelitian tetapi tidak digunakan untuk membuat kesimpulan yang lebih luas".

Metode deskriptif bertujuan untuk mengetahui sifat serta hubungan yang lebih mendalam antar variable dengan cara mengamati aspek-aspek tertentu secara lebih spesifik untuk memperoleh data yang sesuai dengan masalah yang ada dan diproses lebih lanjut dengan dasar teori-teori yang telah dipelajari sehingga data tersebut dapat ditarik sebuah kesimpulan.

\section{Sumber Data}


Sumber data yang digunakan dalam penelitian ini adalah data sekunder. Menurut Sugiyono (2012:21) "data sekunder, yaitu data yang diperoleh dari perusahaan sebagai obyek penelitian yang sudah diolah dan terdokumentasi di perusahaan, misalnya sejarah perusahaan, struktur organisasi, dan laporan keuangan perusahaan."

Secara spesifik sumber data yang diperlukan adalah dokumen berupa laporan keuangan neraca dan laporan laba-rugi

\section{Teknik Analisis Data}

Untuk memecahkan masalah dalam penelitian ini, maka penulis menggunakan metode deskriptif dengan menggunakan analisis rasio keuangan sebagai berikut:
Aktiva lancar
1. Current Ratio $=$
Hutang lancar
Kas + Efek + Piutang
2. Quick Ratio $=$---------------------

3. Penjualan netto - Harga pokok penjualan
Penjualan Netto
Penjualan netto - HPP - Biaya

$$
\text { Penjualan netto - HPP - Biaya }
$$

Penjualan Netto

5. Total Debt to Equity Ratio $=\frac{\text { Hutang lancar + Hutang Jangka Panjang }}{-\mathrm{y}}$

6. Total Debt to Capital Assets = Hutang lancar + Hutang Jangka Panjang

\section{Jumlah Modal/Aktiva}

7. Receivable Turnover $=\frac{\text { Penjualan kredit }}{\text { Piutang rata-rata }}$

8. Total Assets Turnover $=\frac{\text { Penjualan netto }}{\text { Jumlah aktiva }}$

D. HASIL ANALISIS DATA

\section{Rasio Likuiditas}

Rasio likuiditas yaitu rasio yang menunjukkan kemampuan perusahaan untuk membayar semua kewajiban finansial jangka pendek. Menurut Kasmir 
(2009:131) Jika dilakukan analisis pada laporan keuangan, kondisi rasio likuiditas akan tampak sebagai berikut:

a) Current Ratio

Rasio untuk menghitung kemampuan perusahaan untuk membayar hutang segera harus dipenuhi dengan aktiva lancar.

Berdasarkan data laporan keuangan neraca tahun 2010-2012 pada lampiran 1, menunjukkan bahwa kondisi current ratio PT. Astalia Millenia Educatindo cabang Madiun adalah sebagai berikut:

$$
\begin{aligned}
& \text { Current Ratio }=\underline{\text { Aktiva lancar }} \\
& \text { Hutang lancar } \\
& \text { Tahun } 2010=\frac{283.283 .218}{206.268 .924} \\
& =1,37 \text { atau } 137 \%
\end{aligned}
$$

Tahun $2011=\underline{495.666 .658}$

328.172 .968

$$
=1,51 \text { atau } 151 \%
$$

Tahun $2012=\frac{713.357 .552}{464.566 .597}$

$$
=1,54 \text { atau } 154 \%
$$

Current Ratio PT. Astalia Millenia Educatindo cabang Madiun pada tahun 2010 sebesar 1,37 atau 137\% yang berarti setiap hutang lancar Rp 1,00 dijamin oleh aktiva lancar Rp 1,37. Pada tahun 2011 meningkat 10,2\% sebesar 1,51 atau $151 \%$ yang berarti setiap hutang lancar $\mathrm{Rp} 1,00$ dijamin oleh aktiva lancar $\mathrm{Rp} \mathrm{1,51.} \mathrm{Sedangkan} \mathrm{pada} \mathrm{tahun} 2012$ juga meningkat $2 \%$ sebesar 1,54 atau $154 \%$ yang berarti setiap hutang lancar $\mathrm{Rp} 1,00$ dijamin oleh aktiva lancar $\mathrm{Rp}$ 1,54. Peningkatan ini disebabkan oleh meningkatnya jumlah aktiva lancar.

\section{b) Quick Ratio}

Rasio yang menghitung kemampuan perusahaan untuk membayar hutang yang segera harus dipenuhi dengan aktiva lancar yang lebih likuid. Berdasarkan data laporan keuangan neraca tahun 2010-2012 pada lampiran 1, menunjukkan bahwa kondisi quick ratio PT. Astalia Millenia Educatindo cabang Madiun adalah sebagai berikut:

$$
\begin{aligned}
\text { Quick Ratio } & =\begin{array}{c}
\text { Kas }+ \text { Efek }+ \text { Piutang } \\
\text { Hutang lancar }
\end{array} \\
\text { Tahun } 2010= & \text { 9.035.821 + 272.997.400 } \\
\text { 206.268.924 } & \\
= & 1,37 \text { atau } 137 \% \\
\text { Tahun } 2011= & \frac{51.475 .662+443.191 .000}{328.172 .968} \\
= & 1,51 \text { atau } 151 \%
\end{aligned}
$$




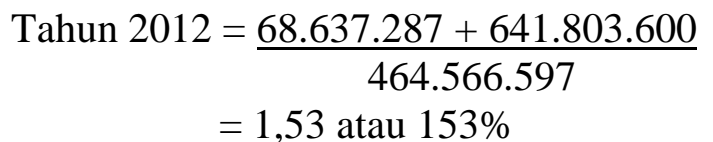

Quick Ratio PT. Astalia Millenia Educatindo cabang Madiun pada tahun 2010 sebesar 1,37 atau 137\% yang berarti setiap hutang lancar Rp 1,00 dijamin oleh aktiva lancar yang lebih likuid (quick asset) Rp 1,37. Pada tahun 2011 meningkat 10,2\% sebesar 1,51 atau 151\% yang berarti setiap hutang lancar Rp 1,00 dijamin oleh quick asset Rp 1,51. Sedangkan pada tahun 2012 meningkat 1,3\% sebesar 1,53 atau $153 \%$ yang berarti setiap hutang lancar Rp 1,00 dijamin oleh quick asset $\mathrm{Rp} 1,53$. Peningkatan ini disebabkan oleh meningkatnya jumlah kas dan piutang.

\section{Rasio Profitabilitas}

Rasio profitabilitas yaitu suatu rasio yang mengukur seberapa efektif menajemen perusahaan menghasilkan keuntungan pada penjualan, aset maupun modal sendiri. Jika dilakukan analisis pada laporan keuangan, kondisi rasio profitabilitas akan tampak sebagai berikut:

a) Gross Profit Margin

Rasio ini mengukur laba bruto per rupiah penjualan. Berdasarkan data laporan laba rugi tahun 2010-2012 pada lampiran 2, menunjukkan bahwa kondisi Gross Profit Margin PT. Astalia Millenia Educatindo cabang Madiun adalah sebagai berikut:

Gross Profit Margin $=\underline{\text { Penjualan netto }- \text { Harga pokok penjualan }}$

$$
\text { Penjualan Netto }
$$

$$
\text { Tahun } \begin{aligned}
2010 & =\frac{119.400 .000-77.610 .000}{119.400 .000} \\
& =0,35 \text { atau } 35 \%
\end{aligned}
$$

Tahun $2011=\underline{306.891 .500-199.479 .150}$

$$
306.891 .500
$$

$$
=0,35 \text { atau } 35 \%
$$

Tahun $2012=\underline{366.209 .400-253.108 .960}$

$$
=0,31 \text { atau } 31 \%
$$

Gross Profit Margin PT. Astalia Millenia Educatindo cabang Madiun pada tahun 2010 sebesar 0,35 atau 35\% yang berarti setiap rupiah penjualan menghasilkan laba bruto $\mathrm{Rp}$ 0,35. Pada tahun 2011 tetap sebesar 0,35 atau $35 \%$ yang berarti setiap rupiah penjualan menghasilkan laba bruto Rp 0,35. Sedangkan pada tahun 2012 turun $11,4 \%$ sebesar 0,31 atau $31 \%$ yang berarti setiap rupiah penjualan menghasilkan laba bruto $\mathrm{Rp} 0,31$. Penurunan yang terjadi pada tahun 2012 disebabkan oleh meningkatnya harga pokok penjualan yang tidak diimbangi dengan meningkatnya penjualan.

b) Operating Profit Margin

Rasio ini mengukur tingkat laba operasi dibandingkan dengan volume penjualan. Berdasarkan data laporan laba rugi tahun 2010-2012 
pada lampiran 2, menunjukkan bahwa kondisi Operating Profit Margin PT. Astalia Millenia Educatindo cabang Madiun adalah sebagai berikut:

Operating Profit Margin $=\underline{\text { Penjualan netto }- \text { Harga pokok penjualan }- \text { biaya }}$

Penjualan netto

Tahun $2010=\frac{119.400 .000-77.610 .000-27.124 .356}{119.400 .000}$ $=0,12$ atau $12 \%$

Tahun $2011=\underline{306.891 .500-199.479 .150-61.258 .366}$ $=0,15$ atau $15 \%$

Tahun $2012=\underline{366.209 .400-253.108 .960-38.247 .502}$

$$
=0,20 \text { atau } 20 \%
$$

Operating Profit Margin PT. Astalia Millenia Educatindo cabang Madiun pada tahun 2010 sebesar 0,12 atau 12\% yang berarti setiap rupiah penjualan menghasilkan laba operasi Rp 0,12. Pada tahun 2011 meningkat $25 \%$ sebesar 0,15 atau $15 \%$ yang berarti setiap rupiah penjualan menghasilkan laba operasi Rp 0,15. Sedangkan pada tahun 2012 meningkat 33,3\% sebesar 0,20 atau $20 \%$ yang berarti setiap rupiah penjualan menghasilkan laba operasi Rp 0,20. Peningkatan ini disebabkan oleh meningkatnya penjualan. Meskipun mulai tahun 2011 harga pokok penjualan meningkat, tetapi diimbangi dengan meningkatnya penjualan yang akhirnya mampu menutup biaya operasional.

\section{Rasio Solvabilitas}

Rasio solvabilitas yaitu suatu rasio yang digunakan untuk mengukur kemampuan perusahaan dalam memenuhi kewajiban jangka panjangnya. Dengan analisis rasio solvabilitas, perusahaan akan mengetahui beberapa hal berkaitan dengan penggunaan modal sendiri dan modal pinjaman serta mengetahui kemampuan perusahaan untuk memenuhi kewajibannya. Jika dilakukan analisis pada laporan keuangan, kondisi rasio solvabilitas akan tampak sebagai berikut:

a) Total Debt to Equity Ratio

Rasio ini menunjukkan berapa bagian dari setiap rupiah modal sendiri yang dijadikan jaminan hutang.

Berdasarkan data laporan keuangan neraca tahun 2010-2012 pada lampiran 1, menunjukkan bahwa kondisi Total Debt to Equity Ratio PT. Astalia Millenia Educatindo cabang Madiun adalah sebagai berikut:

Total Debt to Equity Ratio =

Hutang lancar + Hutang jangka panjang

Jumlah modal sendiri

Tahun $2010=\underline{206.268 .924}$

84.604 .880

$=2,43$ atau $243 \%$

Tahun $2011=\underline{328.172 .968}$ 


$$
\begin{aligned}
& 172.319 .170 \\
= & 1,90 \text { atau } 190 \% \\
\text { Tahun } 2012= & \frac{464.566 .597}{250.922 .182} \\
= & 1,85 \text { atau } 185 \%
\end{aligned}
$$

Total Debt to Equity Ratio PT. Astalia Millenia Educatindo cabang Madiun pada tahun 2010 sebesar 2,43 atau 243\% yang berarti Rp 2,43 dari setiap rupiah modal sendiri menjadi jaminan hutang. Pada tahun 2011 turun $21,8 \%$ sebesar 1,90 atau $190 \%$ yang berarti Rp 1,90 dari setiap rupiah modal sendiri menjadi jaminan hutang. Sedangkan pada tahun 2012 turun 2,6\% sebesar 1,85 atau $185 \%$ yang berarti $\mathrm{Rp} 1,85$ dari setiap rupiah modal sendiri menjadi jaminan hutang. Penurunan ini disebabkan oleh meningkatnya jumlah modal sendiri. Walaupun jumlah hutang juga meningkat yaitu sebesar 59,10\% ditahun 2011 dan 41,56\% ditahun 2012, tetapi peningkatannya tidak sebesar jumlah modal sendiri yaitu sebesar 103,68\% ditahun 2011 dan 44,61\% ditahun 2012 .

b) Total Debt to Capital Asset

Rasio yang mengukur bagian dari aktiva yang digunakan untuk menjamin hutang. Semakin tinggi rasio ini maka semakin besar jumlah modal pinjaman yang digunakan oleh perusahaan.

Berdasarkan data laporan keuangan neraca tahun 2010-2012 pada menunjukkan bahwa kondisi Total Debt to Capital Asset PT. Astalia Millenia Educatindo cabang Madiun adalah sebagai berikut:

Total Debt to Capital Assets $=$ - Hutang lancar + Hutang jangka panjang
Tahun $2010=\frac{206.268 .924}{290.873 .804}$
$=0,71$ atau $71 \%$

Tahun $2011=\underline{328.172 .968}$ 500.492 .138

$$
=0,66 \text { atau } 66 \%
$$

Tahun $2012=\underline{464.566 .597}$

715.488 .779

$$
=0,65 \text { atau } 65 \%
$$

Total Debt to Capital Asset PT. Astalia Millenia Educatindo cabang Madiun pada tahun 2010 sebesar 0,71 atau 71\% yang berarti Rp 0,71 dari setiap rupiah aktiva digunakan untuk menjamin hutang. Pada tahun 2011 turun $93 \%$ sebesar 0,66 atau $66 \%$ yang berarti $\mathrm{Rp} 0,66$ dari setiap rupiah aktiva digunakan untuk menjamin hutang. Sedangkan pada tahun 2012 juga turun 1,5\% sebesar 0,65 atau 65\% yang berarti Rp 0,65 dari setiap rupiah aktiva digunakan untuk menjamin hutang. Penurunan ini disebabkan oleh meningkatnya jumlah aktiva. Meskipun jumlah hutang juga meningkat yaitu sebesar 59,10\% ditahun 2011 dan 41,56\% ditahun 
2012, tetapi peningkatannya tidak sebesar jumlah aktiva yaitu sebesar $72,07 \%$ ditahun 2011 dan 42,96\% ditahun 2012

\section{Rasio Aktivitas}

Rasio aktivitas, yaitu suatu rasio yang mengukur seberapa efektif perusahaan menggunakan berbagai aktivanya. Pada perusahaan diharapkan adanya keseimbangan antara penjualan dengan aktiva seperti persediaan, piutang dan aktiva tetap lainnya. Jika dilakukan analisis pada laporan keuangan, kondisi rasio aktivitas akan tampak sebagai berikut:

a) Receivable Turnover

Rasio yang menunjukkan kemampuan dana yang tertanam dalam piutang berputar dalam suatu periode tertentu.

Berdasarkan data laporan keuangan neraca dan laporan laba rugi tahun 2010-2012 pada lampiran 1\&2, menunjukkan bahwa kondisi Receivable Turnover PT. Astalia Millenia Educatindo cabang Madiun adalah sebagai berikut:

$$
\text { Receivable Turnover = } \frac{\text { Penjualan kredit }}{\text { Piutang rata-rata }}
$$

$$
\text { Tahun } \begin{aligned}
2010 & =\frac{119.400 .000}{272.997 .400} \\
& =0,44 \text { atau } 0,4 \mathrm{x}
\end{aligned}
$$

Tahun $2011=\underline{306.891 .500}$

443.191 .000

$$
=0,69 \text { atau } 0,7 \mathrm{x}
$$

Tahun $2012=\frac{366.209 .400}{641.803 .600}$

$$
=0,57 \text { atau } 0,6 \mathrm{x}
$$

Receivable Turnover PT. Astalia Millenia Educatindo cabang Madiun pada tahun 2010 sebesar 0,44 atau 0,4 x yang berarti dalam satu tahun rata-rata dana yang tertanam dalam piutang berputar $0,4 \mathrm{x}$. Pada tahun 2011 meningkat 56,8\% sebesar 0,69 atau $0,7 \times$ yang berarti dalam satu tahun rata-rata dana yang tertanam dalam piutang berputar $0,7 \mathrm{x}$. Sedangkan pada tahun 2012 turun 17,4\% sebesar 0,57 atau 0,6 x yang berarti dalam satu tahun rata-rata dana yang tertanam dalam piutang berputar 0,6 x.

Penurunan yang terjadi pada tahun 2012 disebabkan oleh meningkatnya piutang rata-rata. Meskipun penjualan kredit ditahun 2012 juga meningkat sebesar $19,33 \%$, tetapi peningkatan piutang rata-rata ditahun 2012 lebih besar yaitu 44,81\%

\section{b) Total Asset Turnover}

Rasio yang menunjukkan kemampuan dana yang tertanam dalam keseluruhan aktiva berputar dalam suatu periode tertentu atau kemampuan modal yang diinvestasikan untuk menghasilkan pendapatan. 
Berdasarkan data laporan keuangan neraca dan laporan laba rugi tahun 2010-2012, menunjukkan bahwa kondisi Total Asset Turnover PT. Astalia Millenia Educatindo cabang Madiun adalah sebagai berikut:

Penjualan netto

$$
\text { Total Assets Turnover }=\text {------------------- }
$$

$$
\text { Tahun } \begin{aligned}
2010 & =\frac{119.400 .000}{290.873 .804} \\
& =0,41 \text { atau } 0,4 \mathrm{x}
\end{aligned}
$$

Tahun $2011=\underline{306.891 .500}$

$$
500.492 .138
$$$$
=0,61 \text { atau } 0,6 \mathrm{x}
$$

Tahun $2012=\underline{366.209 .400}$

715.488 .779

$$
=0,51 \text { atau } 0,5 \mathrm{x}
$$

Total Asset Turnover PT. Astalia Millenia Educatindo cabang Madiun pada tahun 2010 sebesar 0,41 atau 0,4 x yang berarti dana yang tertanam dalam keseluruhan aktiva rata-rata dalam satu tahun berputar 0,4 $\mathrm{x}$ atau setiap rupiah aktiva selama satu tahun dapat menghasilkan revenue sebesar Rp 0,41. Pada tahun 2011 meningkat 48,8\% sebesar 0,61 atau 0,6 x yang berarti dana yang tertanam dalam keseluruhan aktiva rata-rata dalam satu tahun berputar 0,6 $\mathrm{x}$ atau setiap rupiah aktiva selama satu tahun dapat menghasilkan revenue sebesar Rp 0,61. Sedangkan pada tahun 2012 turun $16,4 \%$ sebesar 0,51 atau $0,5 \times$ yang berarti dana yang tertanam dalam keseluruhan aktiva rata-rata dalam satu tahun berputar $0,5 \mathrm{x}$ atau setiap rupiah aktiva selama satu tahun dapat menghasilkan revenue sebesar $\mathrm{Rp}$ 0,51 .

Penurunan yang terjadi pada tahun 2012 disebabkan oleh meningkatnya jumlah aktiva. Meskipun penjualan netto ditahun 2012 juga meningkat sebesar $19,33 \%$, tetapi peningkatan jumlah aktiva ditahun 2012 lebih besar yaitu 42,96\%

Dari hasil perhitungan analisis rasio keuangan, maka dapat diketahui gambaran mengenai tingkat likuiditas, profitabilitas, solvabilitas dan aktivitas yang dicapai oleh perusahaan. Untuk lebih jelasnya, berikut akan disajikan ringkasan data hasil perhitungan kinerja keuangan berdasarkan rasio likuiditas, profitabilitas, solvabilitas dan aktivitas pada PT. Astalia Millenia Educatindo cabang Madiun dari tahun 2010 sampai dengan tahun 2012 adalah sebagai berikut:

Tabel 1 : Hasil perhitungan kinerja keuangan

\begin{tabular}{|c|l|c|c|c|c|}
\hline \multirow{2}{*}{ No. } & \multicolumn{1}{|c|}{ Rasio } & \multicolumn{3}{|c|}{ Hasil Analisis } & \multirow{2}{*}{ Keterangan } \\
\cline { 3 - 5 } & & 2010 & 2011 & 2012 & \\
\hline & Likuiditas & $137 \%$ & $151 \%$ & $154 \%$ & meningkat \\
& $\begin{array}{l}\text { a. Current Ratio } \\
\text { b. Quick Ratio }\end{array}$ & $137 \%$ & $151 \%$ & $153 \%$ & meningkat \\
\hline 2 & Profitabilitas & & & & \\
\hline
\end{tabular}




\begin{tabular}{|c|l|c|c|c|l|} 
& a. Gross Profit Margin & $35 \%$ & $35 \%$ & $31 \%$ & $\begin{array}{l}\text { fluktuasi } \\
\text { meningkat }\end{array}$ \\
\hline 3 & b. Operating Profit Margin & $12 \%$ & $15 \%$ & $20 \%$ & \\
& $\begin{array}{l}\text { Solvabilitas } \\
\text { a. Total Debt to Equity Ratio }\end{array}$ & $243 \%$ & $190 \%$ & $185 \%$ & turun \\
& b. Total Debt to Capital Asset & $71 \%$ & $66 \%$ & $65 \%$ & turun \\
\hline \multirow{2}{*}{4} & Aktivitas & & & & \\
& a. Receivable Turnover & $0,4 \mathrm{x}$ & $0,7 \mathrm{x}$ & $0,6 \mathrm{x}$ & fluktuasi \\
& b. Total Asset Turnover & $0,4 \mathrm{x}$ & $0,6 \mathrm{x}$ & $0,5 \mathrm{x}$ & fluktuasi \\
\hline
\end{tabular}

Sumber data: diolah dari hasil laporan keuangan PT. AME cabang Madiun

Sedangkan jika hasil perhitungan analisis rasio keuangan dibandingkan dengan rata-rata industri dan safety standard perusahaan, maka hasilnya adalah sebagai berikut:

Tabel 2 : Perbandingan hasil analisis rasio keuangan dengan rata-rata industri dan safety standard perusahaan

\begin{tabular}{|c|c|c|c|c|c|c|}
\hline \multirow{2}{*}{ No } & \multirow{2}{*}{ Rasio } & \multicolumn{3}{|c|}{ PT. AME } & \multirow{2}{*}{$\begin{array}{c}\text { rata-rata } \\
\text { industri }\end{array}$} & \multirow{2}{*}{$\begin{array}{c}\text { safety } \\
\text { standard } \\
\text { perusahaan }\end{array}$} \\
\hline & & 2010 & 2011 & 2012 & & \\
\hline 1 & $\begin{array}{l}\text { Likuiditas } \\
\text { a. Current Ratio } \\
\text { b. } \quad \text { Quick Ratio }\end{array}$ & $\begin{array}{l}1,3 \mathrm{x} \\
1,3 \mathrm{x}\end{array}$ & $\begin{array}{l}1,5 \mathrm{x} \\
1,5 \mathrm{x}\end{array}$ & $\begin{array}{l}1,5 \mathrm{x} \\
1,5 \mathrm{x}\end{array}$ & $\begin{array}{c}2 \mathrm{x} \\
1,5 \mathrm{x}\end{array}$ & $\begin{array}{c}2 \mathrm{x} \\
1,5 \mathrm{x}\end{array}$ \\
\hline 2 & $\begin{array}{l}\text { Profitabilitas } \\
\text { a. } \quad \text { Gross Profit Margin } \\
\text { b. } \quad \text { Operating Profit Margin }\end{array}$ & $\begin{array}{l}35 \% \\
12 \%\end{array}$ & $\begin{array}{l}35 \% \\
15 \%\end{array}$ & $\begin{array}{l}31 \% \\
20 \% \\
\end{array}$ & $\begin{array}{l}30 \% \\
20 \%\end{array}$ & $\begin{array}{l}30 \% \\
20 \%\end{array}$ \\
\hline 3 & $\begin{array}{l}\text { Solvabilitas } \\
\text { a. } \text { Total Debt to Equity Ratio } \\
\text { b. } \quad \text { Total Debt to Capital Asset }\end{array}$ & $\begin{array}{c}243 \% \\
71 \%\end{array}$ & $\begin{array}{l}190 \% \\
66 \%\end{array}$ & $\begin{array}{c}185 \\
\% \\
65 \%\end{array}$ & $\begin{array}{l}90 \% \\
35 \%\end{array}$ & $\begin{array}{l}90 \% \\
35 \%\end{array}$ \\
\hline 4 & $\begin{array}{l}\text { Aktivitas } \\
\text { a. Receivable Turnover } \\
\text { b. Total Asset Turnover }\end{array}$ & $\begin{array}{l}0,4 \times \\
0,4 \times\end{array}$ & $\begin{array}{l}0,7 \times \\
0,6 \times\end{array}$ & $\begin{array}{l}0,6 \mathrm{x} \\
0,5 \mathrm{x}\end{array}$ & $\begin{array}{c}15 \mathrm{x} \\
2 \mathrm{x}\end{array}$ & $\begin{array}{c}15 \mathrm{x} \\
2 \mathrm{x}\end{array}$ \\
\hline
\end{tabular}

Sumber data: diolah dari hasil laporan keuangan PT. AME cabang Madiun

Dari pembahasan diatas dapat kemampuan PT. Astalia Millenia Educatindo cabang Madiun dalam membayar hutang jangka pendeknya dengan asset paling lancar yang dimilikinya mengalami peningkatan dari tahun 2010 sampai dengan tahun 2012. Jika rata-rata industri dan safety standard perusahaan untuk quick ratio adalah 1,5 kali, maka pada tahun 2010 perusahaan dalam kondisi kurang baik karena masih dibawah rata-rata industri. Tetapi ditahun 2011 \& 2012, perusahaan dalam kondisi baik.

Kemampuan PT. Astalia Millenia Educatindo cabang Madiun dalam menghasilkan laba bruto per rupiah penjualan mengalami fluktuasi dari tahun 2010 sampai dengan tahun 2012. Jika rata-rata industri dan safety standard perusahaan untuk gross profit margin adalah 30\%, margin laba perusahaan tahun 2010 sampai tahun 2012 masih dalam kondisi baik karena masih di atas rata-rata industri dan safety standard perusahaan. 
Kemampuan PT. Astalia Millenia Educatindo cabang Madiun dalam menghasilkan laba operasi yang dibandingkan dengan volume penjualannya mengalami peningkatan dari tahun 2010 sampai dengan tahun 2012. Namun, jika dibandingkan dengan rata-rata industri dan safety standard perusahaan untuk operating profit margin adalah $20 \%$ maka hanya ditahun 2012 saja perusahaan mampu mengamankan kondisi keuangan. Sedangkan pada tahun 2010 \& 2011 operating profit margin jauh dibawah rata-rata industri dan safety standard perusahaan. Hal ini ada kemungkinan meningkatnya biaya tidak langsung yang relatif tinggi terhadap penjualan untuk periode tersebut.

Kemampuan PT. Astalia Millenia Educatindo cabang Madiun dalam menjadikan setiap rupiah modal sendiri sebagai jaminan hutangnya mengalami penurunan dari tahun 2010 sampai dengan tahun 2012. Meskipun dari tahun ketahun rasio solvabilitas mengalami penurunan, namun jika rasio rata-rata industri dan safety standard perusahaan untuk total debt to equity ratio adalah $90 \%$, maka perusahaan dalam keadaan tidak baik karena berada di atas rata-rata industri dan safety standard perusahaan.

Kemampuan PT. Astalia Millenia Educatindo cabang Madiun dalam menjadikan setiap rupiah aktiva sebagai jaminan hutangnya mengalami penurunan dari tahun 2010 sampai dengan tahun 2012. Namun jika dilihat dari rata-rata industri dan safety standard perusahaan untuk Total debt to capital asset yaitu 35\%, maka perusahaan dalam kondisi tidak baik. Total debt to capital asset perusahaan masih diatas rata-rata industri dan safety standard perusahaan sehingga akan sulit bagi perusahaan untuk memperoleh pinjaman. Melihat kondisi tersebut, perusahaan dibiayai hampir seluruhnya oleh hutang. Jika perusahaan bermaksud menambah hutang, maka perusahaan harus menambah dulu ekuitasnya.

Jumlah dana PT. Astalia Millenia Educatindo cabang Madiun yang tertanam dalam piutang berputar untuk satu periode tertentu mengalami fluktuasi dari tahun 2010 sampai dengan tahun 2012. Jika dilihat rata-rata industri dan safety standard perusahaan untuk perputaran piutang adalah 15 $\mathrm{x}$, maka penagihan piutang oleh perusahaan dianggap tidak berhasil karena jauh dibawah rata-rata industri.

Jumlah dana PT. Astalia Millenia Educatindo cabang Madiun yang tertanam dalam keseluruhan aktiva berputar untuk satu periode tertentu atau kemampuan modal yang diinvestasikan untuk menghasilkan pendapatan mengalami fluktuasi dari tahun 2010 sampai dengan tahun 2012. Jika dilihat rata-rata industri dan safety standard perusahaan untuk total asset turnover adalah $2 \mathrm{x}$, berarti perusahaan belum mampu memaksimalkan aktiva yang dimiliki. Diharapkan perusahaan mampu meningkatkan penjualannya ataupun mengurangi sebagian aktiva yang kurang produktif.

\section{E. KESIMPULAN \\ a. Kesimpulan}

Berdasarkan hasil analisis dan pembahasan yang telah dikemukakan penulis pada bab sebelumnya, maka dapat disimpulkan kinerja keuangan pada 
PT. Astalia Millenia Educatindo cabang Madiun pada tahun 2010 sampai dengan tahun 2012 sebagai berikut:

1. Kinerja keuangan pada PT. Astalia Millenia Educatindo cabang Madiun ditinjau dari rasio likuiditas pada tahun 2010 sampai dengan tahun 2012 mengalami peningkatan.

2. Kinerja keuangan pada PT. Astalia Millenia Educatindo cabang Madiun ditinjau dari rasio profitabilitas pada tahun 2010 sampai dengan tahun 2012 cenderung mengalami peningkatan.

3. Kinerja keuangan pada PT. Astalia Millenia Educatindo cabang Madiun ditinjau dari rasio solvabilitas pada tahun 2010 sampai dengan tahun 2012 mengalami peningkatan.

4. Kinerja keuangan pada PT. Astalia Millenia Educatindo cabang Madiun ditinjau dari rasio aktivitas pada tahun 2010 sampai dengan tahun 2012 berfluktuasi.

\section{b. Saran}

Berdasarkan pembahasan dan kesimpulan yang telah dikemukakan diatas, maka penulis mencoba memberikan saran dengan harapan dapat bermanfaat bagi pihak manajemen perusahaan sehubungan dengan kondisi keuangan pada PT. Astalia Millenia Educatindo cabang Madiun dari tahun 2010 sampai dengan tahun 2012, diantaranya sebagai berikut:

1. Rasio profitabilitas perusahaan belum menunjukkan peningkatan yang memuaskan. Harga pokok penjualan memang sering menjadi kendala, namun disarankan perusahaan juga mampu memperhitungkan laba yang akan diperoleh. Meningkatkan penjualan bisa dengan cara meningkatkan promosi produk. Namun demikian, kegiatan operasional juga lebih diefektifkan, agar biaya operasional tidak semakin besar. Persaingan dengan perusahaan sejenis juga menjadi salah satu kendala perusahaan tidak bisa memaksimalkan laba. Pihak manajemen perlu mengambil tindakan agar mendapat kepercayaan dari para konsumen, misalnya dengan pelayanan yang baik, after sales service yang memuaskan, serta hubungan baik dengan para konsumen.

2. Meskipun rasio solvabilitas perusahaan menunjukkan peningkatan tiap tahunnya, namun masih dibawah rata-rata industri. Perlu kontrol yang baik dari manajemen agar tingkat solvabilitas perusahaan selalu terjaga dengan baik atau bahkan meningkat. Kerjasama antara bagian keuangan dengan bagian pemasaran juga diperlukan. Dimana bagian pemasaran berperan untuk memperluas wilayah kerja agar dapat meningkatkan penjualan. Penjualan yang secara tunai maupun kredit, karena penjualan secara kredit juga sebagai bentuk strategi pemasaran untuk menaikkan penjualan.

3. Rasio aktivitas yang masih rendah, disarankan kepada manajemen untuk lebih mengontrol para debitur untuk dapat memenuhi kewajiban mereka tepat pada waktunya.

4. Kinerja keuangan diharapkan selalu ditinjau secara terus menerus agar perubahan-perubahan yang terjadi pada keuangan perusahaan dapat terlihat dengan jelas. Pihak manajemen dapat mengantisipasi dan dengan cepat mengambil keputusan untuk kemungkinan-kemungkinan yang bisa saja terjadi di masa yang akan dating, serta untuk lebih meningkatkan kinerja perusahaan dimasa yang akan datang. 


\section{DAFTAR PUSTAKA}

Bungin, Burhan, 2005. Metodologi Penelitian Kuantitatif Komunikatif, Ekonomi, dan Kebijakan Publik serta Ilmu-Ilmu Sosial Lainnya. Jakarta: Prenada Media.

Dermawan, 2013. Analisis Laporan Keuangan. Jakarta: Mitrawacanamedia.

Kamus Besar Bahasa Indonesia, 2005. Edisi Ketiga. Jakarta: Balai Pustaka.

Kasmir, 2006. Manajemen Perbankan. Jakarta: PT. Raja Grafindo Persada.

Kasmir, 2009. Analisis Laporan Keuangan. Jakarta: Rajawali Pers.

Mulyadi, 2007. Sistem akuntansi, Jakarta: Salemba Empat.

Munawir, S, 2010. Analisa Laporan Keuangan, Edisi Keempat, Cetakan Kelima Belas, Yogyakarta: Liberty.

Ikatan Akuntan Indonesia, 2009. Standar Akuntansi Keuangan PSAK Penyajian Laporan Keuangan No. 1, Jakarta.

Ikatan Akuntan Indonesia, 2009. Standar Akuntansi Keuangan PSAK Laporan Arus Kas No. 2, Jakarta.

Riyanto, Bambang. 2008. Dasar-Dasar Pembelanjaan Perusahaan. Yogyakarta: GPFE.

Soemarso. 2005. Akuntasi Suatu Pengantar. Jakarta: Salemba Empat.

Sugiyono. 2011. Metode Penelitian Kuantitatif, Kualitatif dan $R$ \& D. Bandung: Alfabeta.

Wild, John J. Subramanyam, K.R. 2011. Analisis Laporan Keuangan. Jakarta: Salemba Empat.

Winarsi, Endang dkk. 2012. Praktikum Manajemen Keuangan. Jakarta: Salemba Empat. 